\title{
Fibrolytic Enzymes to Increase the Nutritive Value of Dairy Feedstuffs ${ }^{1}$
}

\author{
E. A. Elwakeel, E. C. Titgemeyer, ${ }^{2}$ B. J. Johnson, C. K. Armendariz, and J. E. Shirley \\ Department of Animal Sciences and Industry, Kansas State University, Manhattan 66506-1600
}

\begin{abstract}
In vitro studies and a lactation trial were conducted to investigate the effects of fibrolytic enzyme mixtures at different inclusion amounts. Seven enzymes in amounts designed to mimic addition of $1,5,15$, or $30 \mathrm{~g} / \mathrm{d}$ to dairy diets were incubated in vitro with either soybean hulls or alfalfa for 24 or $48 \mathrm{~h}$. Enzyme treatments generally increased in vitro dry matter disappearance (IVDMD), but not volatile fatty acid production. For some enzyme mixtures, lesser amounts of enzymes led to greater increases in IVDMD, whereas for others there were no differences among the amounts tested. The enzyme mixture with the most cellulase activity was the most effective enzyme in improving IVDMD. In additional in vitro experiments, the same enzymes were used at an amount of $5 \mathrm{~g} / \mathrm{d}$, as well as at other amounts that showed promising responses in the first trial. Preincubation of substrates with enzymes before fermentation also was tested. Alfalfa, soybean hulls, corn silage, and corn gluten feed were used as substrates. Preincubation of the substrate with enzymes for $18 \mathrm{~h}$ before in vitro fermentation improved IVDMD. The effect on substrate solubilization of incubating substrates with the enzymes but without rumen fluid was also studied. Addition of enzymes to substrates without subsequent fermentation did not solubilize significant amounts of dry matter, indicating that the positive effect of preincubation cannot be attributed directly to hydrolysis of substrates before the in vitro fermentation with ruminal microbes. The fibrolytic enzyme that appeared most promising in vitro did not affect lactational performance when fed to dairy cows.
\end{abstract}

Key words: enzyme, fiber, digestion

\section{INTRODUCTION}

Grain added to the diets of dairy cows can reduce the ruminal $\mathrm{pH}$ below what is optimal for fibrolytic enzyme

\footnotetext{
Received April 23, 2007.

Accepted June 3, 2007.

${ }^{1}$ Contribution number 05-62-J, Kansas Agricultural Experiment Station, Manhattan.

${ }^{2}$ Corresponding author: etitgeme@ksu.edu
}

activity; therefore, additions to diets of fibrolytic enzymes that can survive such an environment can increase fiber digestion and enhance animal performance (Beauchemin et al., 2003). Fibrolytic enzymes can increase milk production and diet digestibility (Beauchemin et al., 1999; Rode et al., 1999). Yang et al. (1999) reported that enzymes enhanced microbial protein synthesis and protein degradability. Moreover, Rode et al. (1999) showed that enzymes improved digestibility of $\mathrm{DM}$ and fiber from dairy diets. Feng et al. (1996) found that fibrolytic enzymes improved DM digestibility in both in vitro and in situ studies. However, some researchers have not achieved similar positive responses when they used fibrolytic enzymes (Higginbotham et al., 1996; ZoBell et al., 2000). Beauchemin et al. (2003) reported that many factors should be considered when using fibrolytic enzymes to affect animal performance, including enzyme preparation, amount of enzyme, preincubation of feed with the enzymes, moisture content of the substrate, and interaction of the enzyme with the substrate (Beauchemin et al., 2003).

The main objective of our study was to investigate the effect of different amounts of various enzyme preparations on in vitro DM disappearance (IVDMD) and VFA production from 4 different fibrous feedstuffs. In addition, we studied the effect of preincubating the substrate with fibrolytic enzymes. We also studied the effect of the fibrolytic enzyme that in vitro appeared most promising for lactational performance of dairy cows in the presence or absence of supplemental dietary yeast.

\section{MATERIALS AND METHODS}

Procedures involving animal use were approved by the Kansas State University Institutional Animal Care and Use Committee.

\section{General Methods for In Vitro Analysis of Enzymes}

Rumen fluid was collected from 2 ruminally cannulated steers before feeding in the morning. The animals were maintained on a typical dairy diet (50:50 concentrate:forage). Rumen fluid was strained through 4 layers of cheesecloth, kept at $39^{\circ} \mathrm{C}$ in an insulated container, and transported to the laboratory, where it was again 
Table 1. Activities of evaluated enzymes (units/g)

\begin{tabular}{lcccccc}
\hline & \multicolumn{5}{c}{ Activity $^{1}$} \\
\cline { 2 - 6 } Product & Cellulase & Xylanase & $\beta$-glucanase & Pectinase & Galactomannase & Protease \\
\hline FP800 & 25 & 700 & 1,400 & - & - & - \\
XP500 & - & 2,800 & - & - & - & - \\
Mix A & 8 & 700 & 1,400 & - & - & - \\
Mix B & 8 & 700 & 1,400 & 250 & 1,400 & - \\
Mix C & 8 & 700 & 1,400 & - & 1,400 & + Papain \\
Mix D & 8 & 700 & 1,400 & - & 1,400 & + Fradiase \\
Mix E & 8 & 700 & 1,400 & - & - & - \\
\hline
\end{tabular}

\footnotetext{
${ }^{1}$ Enzyme activities as specified by the the manufacturer are micromoles of reducing sugar activity liberated per minute from the appropriate substrates. Cellulase was measured by using filter paper as the substrate. Xylan was from oats. $\beta$-Glucan was from barley.
}

strained through 4 layers of cheesecloth and mixed before incubation.

Fermentations were conducted in 50-mL centrifuge tubes. The substrate weight was $0.30 \mathrm{~g}$, and it was suspended in a mixture of $20 \mathrm{~mL}$ of anaerobic McDougall's buffer with urea (McDougall, 1948) and $10 \mathrm{~mL}$ of strained rumen fluid. All tubes were gassed with $\mathrm{CO}_{2}$ and closed with a stopper with a gas-release valve for experiment 1, and a screw cap with a small hole for experiments 2,3 , and 4 , to keep contents anaerobic but allow fermentative gases to escape. Fermentation was then allowed to progress for either 24 or $48 \mathrm{~h}$. After the appropriate period of time at $39^{\circ} \mathrm{C}$, fermentation was stopped by chilling tubes on ice. Tubes were then centrifuged $(20,000 \times g$ for $20 \mathrm{~min})$. A sample of the liquid (4 $\mathrm{mL}$ ) was mixed with $1 \mathrm{~mL}$ of $25 \%$ (wt/vol) meta-phosphoric acid for analysis of VFA by gas chromatography, and the remaining liquid portion was decanted. The pellet was suspended in an acid-pepsin solution (6.67 $\mathrm{g}$ of 3,000:1 pepsin/L of $1 \mathrm{M} \mathrm{HCl}$ ) and incubated at $39^{\circ} \mathrm{C}$ for $48 \mathrm{~h}$. During incubation, tubes were mixed twice daily. Samples were frozen $\left(-20^{\circ} \mathrm{C}\right)$ and later thawed, and the residue was filtered through Whatman (Clifton, NJ) 541 filter paper, rinsed twice with acetone, oven-dried at $105^{\circ} \mathrm{C}$, and weighed to determine the undigested residue. Blanks containing everything except the substrate were run along with the samples. The IVDMD was calculated as:

$$
\operatorname{IVDMD}=1-[(\mathrm{R}-\mathrm{B}) / \mathrm{S}],
$$

where $R$ is grams of residue of substrate, $B$ is grams of residue of the blank, and $\mathrm{S}$ is dry weight of the initial substrate.

\section{Experiment 1: In Vitro Evaluation of Enzymes}

For this study, 7 enzyme products were tested at 4 different inclusion amounts. All enzyme preparations were provided by Saf Agri (Milwaukee, WI), and activities of the enzymes are provided in Table 1 . The target amounts of enzymes were based on daily amounts that would be provided to a dairy cow consuming $25 \mathrm{~kg} / \mathrm{d}$ of $\mathrm{DM}$ and emulated 1, 5, 15, and $30 \mathrm{~g} / \mathrm{d}$. The amounts used for the fermentations were scaled based on the substrate provided to each in vitro tube $(0.30 \mathrm{~g})$ relative to daily feed intake by a dairy cow $(25 \mathrm{~kg})$. For example, the amount of enzyme added to emulate $1 \mathrm{~g} / \mathrm{d}$ was 0.012 $\mathrm{mg} /$ tube $[1 \mathrm{~g} / \mathrm{d} \times(0.3 \mathrm{~g} / 25,000 \mathrm{~g} / \mathrm{d})]$. Because these amounts of enzyme were very small, we suspended the enzymes in McDougall's buffer with urea and pipetted them to each tube $(0.5 \mathrm{~mL})$.

This study used alfalfa hay and soybean hulls [ground through a 1-mm screen with a Wiley mill (Thomas Scientific, Swedesboro, NJ)] as substrates. The fermentations were conducted for 24 and $48 \mathrm{~h}$ to allow some estimation of the rate $(24 \mathrm{~h}$ ) and extent ( $48 \mathrm{~h}$ ) of fermentation. Each treatment $(7$ enzymes $\times 4$ inclusion rates $\times 2$ substrates $\times 2$ fermentation times) was run in duplicate tubes, and the control (no enzyme) was run in quadruplicate for each substrate and fermentation time.

Data were analyzed by using the MIXED procedure of SAS Release for Windows 8.1 (SAS Inst., Cary, NC). Data were analyzed by ANOVA with a model including terms for fermentation time, amount of enzyme within the source of enzyme, substrate, and all possible interactions among these terms. For all in vitro experiments (experiments 1 through 4 ), the individual test tube was the experimental unit.

\section{Experiments 2 and 3: In Vitro Evaluation of Enzymes}

These experiments evaluated a number of enzyme preparations at different inclusion amounts. Enzyme amounts were selected on the basis of data from experiment 1 . For all products, we tested the amount of $5 \mathrm{~g} /$ $\mathrm{d}$, but we also tested additional inclusion amounts for some of the products because the initial data showed promising results at those amounts. The procedures for experiments 2 and 3 were identical to each other except that experiment 2 used alfalfa hay and soybean hulls as 
substrates, whereas experiment 3 used corn silage and corn gluten feed.

Each experiment contained a factorial arrangement of treatments that included substrate ( 2 per experiment), enzyme addition (12 enzyme/amount combinations plus a no-enzyme control), enzyme preincubation time ( 1 or $18 \mathrm{~h}$ ), and fermentation time ( 24 and $48 \mathrm{~h}$ ). The preincubation period represented the time from which the enzymes were added to the tubes until the rumen fluid inoculum was added; the 1-h preincubation represented the shortest time that could be accommodated by our methodology. During the preincubation period, the tubes were held at $39^{\circ} \mathrm{C}$. Each treatment was conducted in duplicate tubes, and controls (no enzyme) were run in quadruplicate.

Data were analyzed by using the MIXED procedure of SAS. Main effects in the model included fermentation time, amount of enzyme within the source of enzyme, substrate, preincubation time, and all possible interactions among these terms.

\section{Experiment 4: Solubilization of Substrates by Enzymes}

Dry matter solubilized during an 18 -h incubation period with the enzymes was determined by filtering samples that underwent the preincubation only (i.e., no rumen fluid inoculum was added). During the incubation period, the tubes were held at $39^{\circ} \mathrm{C}$. After incubation, samples were filtered through Whatman 541 filter paper, dried at $105^{\circ} \mathrm{C}$, and weighed. Each treatment was conducted in duplicate tubes for each of 4 substrates, and controls (no enzyme) were run in quadruplicate for each substrate. Data were analyzed by using the MIXED procedure of SAS. Terms in the model included substrate, amount of enzyme within the source of enzyme, and the interaction between these terms.

\section{Lactation Trial}

Twenty-four Holstein cows were maintained in tie stalls and used to evaluate the effects of various levels of the fibrolytic enzyme mixture FP800 (most efficacious enzyme during in vitro analyses) on lactation performance in the presence or absence of dietary addition of a live yeast (Saccharomyces cerevisiae) product (Procreatin-7, Saf Agri). The cows were from the Kansas State University Dairy Teaching and Research Center and averaged 106 DIM at the start of the experiment (range 59 to 239). All cows were treated with bST (Posilac, Monsanto, St. Louis, MO) every 2 wk.

The treatments were arranged as a $4 \times 2$ factorial with the treatments being a) $0,5,10$, or $15 \mathrm{~g} / \mathrm{d}$ of FP800; and b) 0 or $5 \mathrm{~g} / \mathrm{d}$ of yeast. The design of the experiment was a split plot, with the main-plot treatment being amounts of enzyme and the subplot treatment being the yeast. The 4 enzyme treatments were allotted to cows in 6 replicated incomplete (2-period) $4 \times 4$ Latin squares, with the restriction that each pair of enzyme treatments occurred together in a cow an equal number of times. Each of the main-plot periods was $56 \mathrm{~d}$ and was divided into 2 subplot periods of $28 \mathrm{~d}$ each. Within the 2 subplot periods, each cow received no yeast in 1 period and $5 \mathrm{~g} /$ $\mathrm{d}$ of yeast in the other. The order of yeast administration was randomized such that it was provided equally between the subplot periods. Each of the 8 treatment combinations was designed to be replicated 12 times. However, because of issues with animal health, data were collected from only 21 of the 24 cows. The number of observations for each treatment is listed in a subsequent table.

Within each 28-d subplot period, the first 2 wk were used for adaptation to the treatment and the final $2 \mathrm{wk}$ were used for measuring feed intake and milk production. Diets were fed individually to each cow twice daily to allow for 5 to $10 \%$ orts. The diet composition is shown in Table 2. Treatments were weighed individually and top-dressed to the diets by hand-mixing the treatments at each feeding into the top third of the ration within each cow's feed bunk.

Cows were milked twice daily, and milk weight was recorded at each milking. Milk samples were collected on one day each week (a.m./p.m. composite) and analyzed for lactose, fat, protein, and MUN by the Heart of America DHI Laboratory, Manhattan, Kansas. Milk protein, fat, and lactose contents were analyzed by nearinfrared spectroscopy (Bentley 2000 Infrared Milk Analyzer, Bentley Instruments, Chaska, MN; Bentley Instruments, 1984). A modified Berthelot reaction (ChemSpec 150 Analyzer, Bentley Instruments) was used to determine MUN (Bentley Instruments, 1998). Component yields were calculated by multiplying average daily milk weights by the weekly values for milk composition. Cows were weighed and body condition was scored (Wildman et al., 1982) at the beginning of the experiment and at the end of each subplot period.

Samples of feed ingredients were pooled by period for analysis. Wet feedstuffs were monitored weekly to determine DM content, and the diet was altered to account for changes. Orts were weighed once daily to calculate feed intakes. Feed ingredients were analyzed for DM (drying at $105^{\circ} \mathrm{C}$ overnight), $\mathrm{OM}$ (ashing at $450^{\circ} \mathrm{C}$ for 8 h), CP as $6.25 \times \mathrm{N}$ (Nitrogen Analyzer, Leco Corp., St. Joseph, MI), and NDF (with amylase) and ADF (Van Soest et al., 1991) by using the Ankom 200 Fiber Analyzer (Ankom Co., Macedon, NY).

Data were analyzed by using the MIXED procedure of SAS. The model included terms for cow, main-plot 
Table 2. Composition of the diet for the lactation trial

\begin{tabular}{|c|c|}
\hline Item & $\%$ of DM \\
\hline \multicolumn{2}{|l|}{ Ingredient } \\
\hline Corn, ground & 21.8 \\
\hline Corn silage $^{1}$ & 20.2 \\
\hline Wet corn gluten feed ${ }^{2}$ & 20.2 \\
\hline Alfalfa hay ${ }^{3}$ & 16.8 \\
\hline Whole cottonseed ${ }^{4}$ & 8.4 \\
\hline Expeller soybean meal & 7.6 \\
\hline Limestone & 1.34 \\
\hline Fish meal & 1.25 \\
\hline Molasses & 0.94 \\
\hline Sodium bicarbonate & 0.79 \\
\hline Trace mineral salt ${ }^{5}$ & 0.33 \\
\hline Magnesium oxide & 0.20 \\
\hline Vitamin ADE premix ${ }^{6}$ & 0.10 \\
\hline Trace mineral premix ${ }^{7}$ & 0.05 \\
\hline Vitamin E premix ${ }^{8}$ & 0.02 \\
\hline Sodium selenite premix ${ }^{9}$ & 0.01 \\
\hline \multicolumn{2}{|l|}{ Nutrient } \\
\hline $\mathrm{OM}$ & 92.2 \\
\hline $\mathrm{CP}$ & 19.0 \\
\hline $\mathrm{NDF}$ & 29.3 \\
\hline $\mathrm{ADF}$ & 16.1 \\
\hline Ether extract & 4.9 \\
\hline \multicolumn{2}{|c|}{$\begin{array}{l}{ }^{1} \text { Analyzed to contain (DM basis): } 95.0 \% \mathrm{OM}, 8.9 \% \mathrm{CP}, 43.0 \% \mathrm{NDF} \text {, } \\
24.3 \% \mathrm{ADF} \text {, and } 2.4 \% \text { ether extract. }\end{array}$} \\
\hline \multicolumn{2}{|c|}{${ }^{2}$ Analyzed to contain (DM basis): $93.9 \%$ OM, $24.5 \% \mathrm{CP}, 34.8 \% \mathrm{NDF}$, } \\
\hline \multicolumn{2}{|c|}{$10.6 \% \mathrm{ADF}$, and $2.8 \%$ ether extract. } \\
\hline \multicolumn{2}{|c|}{${ }^{3}$ Analyzed to contain (DM basis): $89.6 \%$ OM, $21.4 \% \mathrm{CP}, 37.6 \% \mathrm{NDF}$, } \\
\hline \multicolumn{2}{|c|}{$29.4 \% \mathrm{ADF}$, and $1.6 \%$ ether extract. } \\
\hline \multicolumn{2}{|c|}{${ }^{4}$ Analyzed to contain (DM basis): $96.0 \% \mathrm{OM}, 23.1 \% \mathrm{CP}, 43.8 \% \mathrm{NDF}$, } \\
\hline \multicolumn{2}{|c|}{$35.8 \% \mathrm{ADF}$, and $22.0 \%$ ether extract. } \\
\hline \multicolumn{2}{|c|}{${ }^{5}$ Provided, per kg of dietary DM: $3.2 \mathrm{~g}$ of $\mathrm{NaCl}, 7.9 \mathrm{mg}$ of $\mathrm{Mn}, 7.9$} \\
\hline \multicolumn{2}{|c|}{$\mathrm{mg}$ of $\mathrm{Fe}, 1.6 \mathrm{mg}$ of $\mathrm{Mg}, 1.1 \mathrm{mg}$ of $\mathrm{Cu}, 1.1 \mathrm{mg}$ of $\mathrm{Zn}, 0.23 \mathrm{mg}$ of I, and } \\
\hline \multirow{2}{*}{\multicolumn{2}{|c|}{$\begin{array}{l}{ }^{6} \text { Provided, per kg of dietary DM: } 4,400 \mathrm{IU} \text { of vitamin A, 2,200 IU } \\
\text { of vitamin D, and } 13.2 \mathrm{IU} \text { of vitamin E. }\end{array}$}} \\
\hline & \\
\hline \multirow{2}{*}{\multicolumn{2}{|c|}{$\begin{array}{l}{ }^{7} \text { Provided, per kg of dietary DM: } 13 \mathrm{mg} \text { of } \mathrm{Zn} \text { from zinc Met, } 7 \mathrm{mg} \\
\text { of Mn from manganese Met, } 4.4 \mathrm{mg} \text { of Cu from copper Lys, and } 0.9 \\
\text { mg of Co from cobalt glucoheptonate. }\end{array}$}} \\
\hline & \\
\hline \multicolumn{2}{|c|}{${ }^{8}$ Provided 6.6 IU of vitamin E per kg of dietary DM. } \\
\hline${ }^{9}$ Provided $0.06 \mathrm{mg}$ of $\mathrm{Se}$ & \\
\hline
\end{tabular}

period, enzyme, subplot period within main-plot period, yeast, and yeast $\times$ enzyme. Cow $\times$ main-plot period $\times$ enzyme was included as a random effect and served as the main-plot error term. Linear, quadratic, and cubic effects of enzymes as well as their interactions with yeast were tested by using contrasts for equally spaced treatments.

\section{RESULTS AND DISCUSSION}

\section{Experiment 1: In Vitro Evaluation of Enzymes}

Table 3 presents the effects of enzyme additions on fermentation of alfalfa hay and soybean hulls. The effects of substrate and fermentation time $\times$ substrate were all significant for IVDMD and VFA concentration (data not shown), and they demonstrated the expected responses
Table 3. Effect of enzyme treatment on in vitro DM disappearance (IVDMD) and total VFA concentrations at 24 and $48 \mathrm{~h}$ of fermentation (experiment 1)

\begin{tabular}{|c|c|c|c|c|c|}
\hline \multirow[b]{2}{*}{ Enzyme } & \multirow[b]{2}{*}{ Amount $^{1}$} & \multicolumn{2}{|c|}{ IVDMD $^{2}$} & \multicolumn{2}{|c|}{$\mathrm{VFA}^{3}$} \\
\hline & & $24 \mathrm{~h}$ & $48 \mathrm{~h}$ & $24 \mathrm{~h}$ & $48 \mathrm{~h}$ \\
\hline & & & & 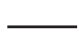 & \\
\hline None & 0 & 63.0 & 74.4 & 86.7 & 100.1 \\
\hline \multirow[t]{4}{*}{ FP800 } & 1 & 69.6 & 81.3 & 86.8 & 93.4 \\
\hline & 5 & 68.3 & 82.2 & 85.2 & 94.5 \\
\hline & 15 & 64.8 & 78.4 & 86.8 & 99.1 \\
\hline & 30 & 64.1 & 78.1 & 86.7 & 96.9 \\
\hline \multirow[t]{4}{*}{ XP500 } & 1 & 64.1 & 79.1 & 87.5 & 98.2 \\
\hline & 5 & 62.7 & 80.5 & 86.6 & 97.9 \\
\hline & 15 & 62.2 & 81.0 & 87.2 & 100.7 \\
\hline & 30 & 64.0 & 79.4 & 85.2 & 94.9 \\
\hline \multirow[t]{4}{*}{ Mix A } & 1 & 60.4 & 79.8 & 84.6 & 101.1 \\
\hline & 5 & 61.5 & 77.3 & 83.4 & 99.0 \\
\hline & 15 & 63.5 & 79.3 & 84.9 & 95.3 \\
\hline & 30 & 64.4 & 78.9 & 85.4 & 96.1 \\
\hline \multirow[t]{4}{*}{ Mix B } & 1 & 62.9 & 74.1 & 84.3 & 98.0 \\
\hline & 5 & 63.1 & 77.5 & 85.4 & 95.0 \\
\hline & 15 & 67.7 & 78.3 & 86.2 & 99.3 \\
\hline & 30 & 65.0 & 79.9 & 83.4 & 102.3 \\
\hline \multirow[t]{4}{*}{ Mix C } & 1 & 65.8 & 83.8 & 84.6 & 102.5 \\
\hline & 5 & 67.9 & 79.8 & 82.6 & 101.1 \\
\hline & 15 & 60.8 & 77.2 & 87.1 & 98.5 \\
\hline & 30 & 60.9 & 76.4 & 85.0 & 99.0 \\
\hline \multirow[t]{4}{*}{ Mix D } & 1 & 64.7 & 79.0 & 84.3 & 98.1 \\
\hline & 5 & 64.8 & 79.2 & 84.1 & 97.8 \\
\hline & 15 & 65.3 & 80.3 & 82.5 & 101.3 \\
\hline & 30 & 66.2 & 81.0 & 82.8 & 99.2 \\
\hline \multirow[t]{4}{*}{ Mix E } & 1 & 63.4 & 76.6 & 88.6 & 102.8 \\
\hline & 5 & 63.4 & 76.6 & 86.5 & 100.0 \\
\hline & 15 & 67.6 & 79.4 & 87.3 & 100.3 \\
\hline & 30 & 66.8 & 78.7 & 86.3 & 101.9 \\
\hline SEM & & $1.2^{4}$ & $1.2^{4}$ & $2.1^{5}$ & $2.1^{5}$ \\
\hline
\end{tabular}

${ }^{1}$ Amounts mimicked the addition of $1,5,15$, or $30 \mathrm{~g} / \mathrm{d}$ of enzyme to diets of dairy cows consuming $25 \mathrm{~kg} / \mathrm{d}$ of DM.

${ }^{2}$ Averages across alfalfa and soybean hulls. Significant effects of fermentation time $(P<0.0001)$, enzyme $(P<0.0001)$, and enzyme $\times$ fermentation time $(P=0.02)$

${ }^{3}$ Averages across alfalfa and soybean hulls. Significant effect of time $(P<0.0001)$. No effects of enzyme $(P=0.47)$ or enzyme $\times$ fermentation time $(P=0.32)$.

${ }^{4}$ SEM for $\mathrm{n}=4$ (all enzyme treatments). SEM for control $(\mathrm{n}=8)=$ 0.88 . Differences among the listed means for enzyme treatments of at least 3.5 are significant $(P=0.05)$. Differences between controls and other means of at least 3.0 are significant $(P=0.05)$.

${ }^{5}$ SEM for $\mathrm{n}=4$ (all enzyme treatments). SEM for control $(\mathrm{n}=8)=$ 1.5 .

for in vitro fermentation of alfalfa and soybean hulls with ruminal fluid. The responses to enzymes were similar between alfalfa hay and soybean hulls (enzyme $\times$ substrate, $P=0.08$ for IVDMD, $P=0.86$ for VFA; data not shown). Thus, within the limits of the 2 substrates and the range of enzymes evaluated, we did not observe any enzyme specificity suggesting that the best choice of an enzyme would be dependent on dietary ingredients.

Enzyme treatment (Table 3$)$ affected $(P<0.01)$ IVDMD but not total VFA concentrations $(P=0.47)$. In general, the response to enzyme treatment was positive 
for IVDMD, and there were clear differences among the enzymes at the different inclusion amounts. In some instances, the lesser amounts of enzymes were more effective in increasing IVDMD than were the greater amounts. This was evident for FP800 and mix C, in which the 1 and $5 \mathrm{~g} / \mathrm{d}$ amounts yielded the greatest IVDMD. There were several enzymes for which the response was similar across all amounts tested (XP500, mixes $\mathrm{A}, \mathrm{B}$, and $\mathrm{D}$ ), and for mix $\mathrm{E}$ the response was better for the greater inclusion amounts ( 15 and $30 \mathrm{~g} /$ d) than for the lesser amounts ( 1 and $5 \mathrm{~g} / \mathrm{d}$ ).

A significant enzyme $\times$ hour of fermentation effect $(P=$ 0.02 ) was present for IVDMD because the responses to enzyme treatment were greater at $48 \mathrm{~h}$ of fermentation than at $24 \mathrm{~h}$. This was not expected; enzymes were expected to increase the rate of digestion rather than the extent of digestion (Feng et al., 1996).

The increased IVDMD in our study is in accordance with the results reported by Yang et al. (1999), in which DM digestibility was increased when alfalfa hay cubes were treated with enzymes and fed to lactating dairy cows. In addition, Feng et al. (1996) found that enzyme treatment of grass forage improved in vitro and in situ DM digestibility. The mode of action by which enzymes can improve digestion is still subject to speculation. Enzyme treatments before feeding were found to increase bacterial colonization of feed particles (Yang et al., 1999), and Yang et al. (1999) proposed that reducing sugars released from the digested portion of the feed attracted bacteria to the site of digestion and enhanced attachment of bacteria to undigested feed particles (Yang et al., 1999; Wang et al., 2001). The solubilized carbohydrate would also provide energy that would lead to rapid microbial growth, shortening the lag time for microbial colonization (Yang et al., 1999). Sutton et al. (2003) reported that enzyme treatments decreased the retention time of digesta in the rumen, which could be attributed to decreased lag time for bacteria to gain attachment to the feed.

Increased rumen enzyme activity is another action by which exogenous enzyme treatment could increase feed digestibility. Hristov et al. (2000) reported that addition of graded amounts of enzymes intraruminally increased rumen enzyme activities of carboxymethylcellulase and xylanase, although Sutton et al. (2003) observed only minor responses to fibrolytic enzymes (predominantly xylanase) infused ruminally. Further, Morgavi et al. (2000) reported a synergistic relationship between fibrolytic enzymes and ruminal enzymes in degrading soluble cellulose, xylans, and corn silage.

Greater IVDMD in experiment 1 with smaller amounts of enzyme FP800 and mix C ( 1 and $5 \mathrm{~g} / \mathrm{d})$ than with greater amounts of the same enzymes (15 and 30 $\mathrm{g} / \mathrm{d}$ ) agrees with the results reported by Beauchemin et al. (1995), in which greater amounts of enzyme preparations added to cubed alfalfa hay and timothy hay did not improve animal performance and DM digestibility compared with that of animals fed smaller amounts of enzymes. Similar findings were reported by Beauchemin et al. (2000). An explanation for these results was provided by Beauchemin et al. (2003), who speculated that excessive enzymes applied to the feed may bind to sites used by rumen bacteria and make them unavailable, creating a barrier against microbial colonization.

Similar to total VFA concentration (Table 3), concentrations of acetate, propionate, and butyrate were not affected by enzyme treatment (data not shown). Although statistically significant effects of enzymes were observed for concentrations of isobutyrate, valerate, and isovalerate, the responses did not seem to be of biological importance (data not shown).

In an in vivo study, Lewis et al. (1996) studied the effect on VFA concentration of treating grass hay and barley with fibrolytic enzymes. They found that enzyme treatment increased total VFA concentration (136 mM) compared with that of the control $(104 \mathrm{mM})$ at $16 \mathrm{~h}$ after feeding. However, enzyme treatment had no effect on molar percentages of individual VFA, which is in accordance with the results we obtained in experiment 1 . Feng et al. (1996) reported no effect of direct-fed enzymes on total VFA concentrations when the enzymes were added to fresh forage and fed to beef steers.

In experiment 1 , many of the enzyme treatments improved IVDMD, but we observed no increases in the production of VFA. Although no statistical differences were present for VFA concentrations, VFA were, in general, numerically less for the enzyme treatments than for the untreated control, which was opposite what is expected when substrate disappearance is increased. We cannot readily explain this paradox, but we observed similar responses in experiments 2 and 3 . This point is of interest, and it may be important for interpreting responses to the enzymes.

\section{Experiments 2 and 3: In Vitro Evaluation of Enzymes}

Effect of Preincubation with Enzymes. The IVDMD values were corrected by using blank values from fermentation tubes without substrate or enzyme. This point deserves emphasis because the blank tubes for the 1- and 18-h preincubations contained slightly different amounts of residues, which led to the larger calculated IVDMD for the 18-h preincubations relative to the 1-h preincubations. Without the blank corrections, the differences in IVDMD between the 2 preincubation times, averaged over experiments 2 and 3 , were essentially zero (data not shown). We have no explanation for 
Table 4. Effects of length of fermentation ( 24 or $48 \mathrm{~h}$ ), enzyme preincubation ( 1 or $18 \mathrm{~h}$ ), and enzyme addition on in vitro DM disappearance (\%; experiments 2 and 3 )

\begin{tabular}{|c|c|c|c|c|c|c|c|c|c|}
\hline \multirow[b]{3}{*}{ Enzyme } & \multirow[b]{3}{*}{ Amount $^{1}$} & \multicolumn{4}{|c|}{ Exp. $2^{2}$} & \multicolumn{4}{|c|}{ Exp. $3^{3}$} \\
\hline & & \multicolumn{2}{|c|}{$24 \mathrm{~h}$} & \multicolumn{2}{|c|}{$48 \mathrm{~h}$} & \multicolumn{2}{|c|}{$24 \mathrm{~h}$} & \multicolumn{2}{|c|}{$48 \mathrm{~h}$} \\
\hline & & $1 \mathrm{~h}$ & $18 \mathrm{~h}$ & $1 \mathrm{~h}$ & $18 \mathrm{~h}$ & $1 \mathrm{~h}$ & $18 \mathrm{~h}$ & $1 \mathrm{~h}$ & $18 \mathrm{~h}$ \\
\hline None & 0 & 59.6 & 66.5 & 67.1 & 70.7 & 66.3 & 70.4 & 74.1 & 74.4 \\
\hline FP800 & 0.3 & 51.3 & 69.3 & 74.2 & 75.9 & 71.0 & 69.9 & 76.1 & 79.0 \\
\hline FP800 & 1 & 55.1 & 69.5 & 74.4 & 78.3 & 71.1 & 69.7 & 75.6 & 84.1 \\
\hline FP800 & 3 & 47.3 & 72.1 & 73.3 & 77.5 & 69.8 & 66.9 & 71.4 & 79.9 \\
\hline FP800 & 5 & 57.5 & 72.8 & 72.4 & 76.8 & 69.9 & 70.1 & 76.5 & 84.7 \\
\hline XP500 & 5 & 52.8 & 67.4 & 70.9 & 77.1 & 69.6 & 69.3 & 76.3 & 83.2 \\
\hline Mix A & 5 & 51.2 & 65.6 & 66.7 & 74.2 & 66.8 & 69.7 & 73.8 & 78.4 \\
\hline Mix B & 5 & 59.3 & 67.3 & 72.3 & 75.6 & 71.2 & 67.8 & 76.6 & 79.9 \\
\hline Mix C & 1 & 51.1 & 67.3 & 72.9 & 74.5 & 70.4 & 66.8 & 72.7 & 77.4 \\
\hline Mix $C$ & 5 & 55.4 & 66.9 & 74.5 & 74.7 & 74.2 & 77.7 & 73.7 & 81.1 \\
\hline Mix D & 5 & 52.8 & 67.8 & 67.7 & 74.3 & 68.9 & 70.4 & 74.9 & 79.8 \\
\hline Mix D & 15 & 56.5 & 68.0 & 71.8 & 70.9 & 70.5 & 70.8 & 75.7 & 81.7 \\
\hline Mix E & 5 & 57.0 & 65.1 & 67.6 & 71.5 & 65.5 & 68.5 & 72.7 & 77.0 \\
\hline SEM & & $1.8^{4}$ & $1.8^{4}$ & $1.8^{4}$ & $1.8^{4}$ & $2.4^{5}$ & $2.4^{5}$ & $2.4^{5}$ & $2.4^{5}$ \\
\hline
\end{tabular}

${ }^{1}$ Amounts mimicked the addition of $0.3,1,3,5$, or $15 \mathrm{~g} / \mathrm{d}$ of enzyme to the diets of dairy cows consuming $25 \mathrm{~kg} / \mathrm{d}$ of DM.

${ }^{2}$ Averages across alfalfa and soybean hulls. Significant effect of enzyme $(P<0.001)$, fermentation time (FT; $P<0.0001)$, preincubation time (PI; $P<0.0001)$, enzyme $\times$ FT $(P<0.001)$, enzyme $\times$ PI $(P<0.01)$, FT $\times \mathrm{PI}(P<0.0001)$, and enzyme $\times \mathrm{FT} \times \mathrm{PI}(P=0.01)$.

${ }^{3}$ Averages across corn gluten feed and corn silage. Significant effect of enzyme $(P<0.01)$, FT $(P<0.0001)$, PI $(P<0.0001)$, and FT $\times$ PI $(P=0.0001)$. No significant effects for enzyme $\times$ FT $(P=0.52)$, enzyme $\times$ PI $(P=0.95)$, and enzyme $\times \mathrm{FT} \times \mathrm{PI}(P=0.48)$.

${ }^{4} \mathrm{SEM}$ for $\mathrm{n}=4$ (all enzyme treatments). SEM for control $(\mathrm{n}=8)=1.3$. Differences among the listed means for enzyme treatment of at least 5.0 are significant $(P=0.05)$. Differences between controls and other means of at least 4.4 are significant $(P=0.05)$.

${ }^{5} \mathrm{SEM}$ for $\mathrm{n}=4$ (all enzyme treatments). SEM for control $(\mathrm{n}=8)=1.7$. Differences among the listed means for enzyme treatments of at least 6.8 are significant $(P=0.05)$. Differences between controls and other means of at least 5.9 are significant $(P=0.05)$.

the difference in these blanks. However, because the blanks are common within each preincubation treatment, this issue does not influence either the treatment responses (except the effect of preincubation) or the significance of any interactions between those means and the preincubation period.

Preincubation times of $18 \mathrm{~h}$ led to greater IVDMD than did 1-h preincubations, but, in addition to the concerns expressed previously regarding blank corrections, the responses were dependent on the other treatments that were applied (Table 4). For example, in experiment 2, extending the preincubation time from 1 to $18 \mathrm{~h}$ led to a much greater increase in IVDMD in the 24 -h fermentations than in the 48-h fermentations. However, the opposite response was observed in experiment 3 , in which the response to extending the preincubation period from 1 to $18 \mathrm{~h}$ was greater at $48 \mathrm{~h}$ than at $24 \mathrm{~h}$ of fermentation $(P<0.01$ for preincubation time $\times$ fermentation time for both experiments 2 and 3 ). With regard to the effects of preincubation time, VFA concentrations did not follow the same pattern as IVDMD in experiments 2 and 3 (Table 5). This lack of a relationship between VFA and IVDMD was discussed for experiment 1.
Morgavi et al. (2001) reported that exogenous enzymes fed to animals are stable in the rumen against rumen proteases for a period of $6 \mathrm{~h}$. However, Lewis et al. (1996), Forwood et al. (1990), and Beauchemin et al. (1999) reported that exogenous enzymes should be applied to diets before feeding. For example, Lewis et al. (1996) found that DM digestibility of a grass hay-based ration increased when enzymes were applied to the diet either 0 or $24 \mathrm{~h}$ before feeding compared with direct infusion of enzymes into the rumen $2 \mathrm{~h}$ after feeding. Forwood et al. (1990) reported that IVDMD was increased when enzymes were preincubated with the forage at room temperature for various periods of time. These findings highlighted the importance of adsorption and binding of the enzyme to substrate before feeding to allow proper attachment and protection against degradation by rumen proteases (Forwood et al., 1990; Beauchemin et al., 2003). Because our shortest period of preincubation was $1 \mathrm{~h}$, it is possible that all treatments had adequate time to bind fibers prior to addition of ruminal fluid.

Effect of Enzymes on IVDMD. As in experiment 1, the response to enzymes was similar among the substrates for IVDMD $(P=0.49$ in experiment 2 and $P=$ 
Table 5. Effects of length of fermentation ( 24 or $48 \mathrm{~h}$ ), enzyme preincubation (1 or $18 \mathrm{~h}$ ), and enzyme addition on total VFA concentrations ( $\mathrm{m} M$; experiments 2 and 3 )

\begin{tabular}{|c|c|c|c|c|c|c|c|c|c|}
\hline \multirow[b]{3}{*}{ Enzyme } & \multirow[b]{3}{*}{ Amount $^{1}$} & \multicolumn{4}{|c|}{ Exp. $2^{2}$} & \multicolumn{4}{|c|}{ Exp. $3^{3}$} \\
\hline & & \multicolumn{2}{|c|}{$24 \mathrm{~h}$} & \multicolumn{2}{|c|}{$48 \mathrm{~h}$} & \multicolumn{2}{|c|}{$24 \mathrm{~h}$} & \multicolumn{2}{|c|}{$48 \mathrm{~h}$} \\
\hline & & $1 \mathrm{~h}$ & $18 \mathrm{~h}$ & $1 \mathrm{~h}$ & $18 \mathrm{~h}$ & $1 \mathrm{~h}$ & $18 \mathrm{~h}$ & $1 \mathrm{~h}$ & $18 \mathrm{~h}$ \\
\hline None & 0 & 78.3 & 69.7 & 92.6 & 91.5 & 70.4 & 74.2 & 73.8 & 80.9 \\
\hline FP800 & 0.3 & 81.1 & 85.9 & 86.2 & 78.8 & 69.7 & 75.9 & 74.1 & 74.9 \\
\hline FP800 & 1 & 79.1 & 84.4 & 88.3 & 85.4 & 73.8 & 70.8 & 73.5 & 68.8 \\
\hline FP800 & 3 & 74.7 & 80.1 & 85.8 & 81.6 & 70.5 & 70.1 & 76.8 & 74.5 \\
\hline FP800 & 5 & 73.0 & 84.9 & 88.8 & 82.3 & 76.5 & 74.8 & 75.7 & 72.2 \\
\hline XP500 & 5 & 77.1 & 69.5 & 87.0 & 79.2 & 71.6 & 72.2 & 73.6 & 81.4 \\
\hline Mix A & 5 & 76.6 & 72.8 & 92.7 & 68.0 & 71.7 & 73.2 & 71.5 & 81.2 \\
\hline Mix B & 5 & 78.1 & 66.3 & 83.4 & 81.4 & 69.4 & 73.2 & 72.9 & 85.2 \\
\hline Mix $C$ & 1 & 77.6 & 87.8 & 89.2 & 84.7 & 69.7 & 75.6 & 75.1 & 74.0 \\
\hline Mix C & 5 & 79.7 & 83.9 & 87.6 & 79.2 & 74.4 & 73.9 & 76.5 & 75.3 \\
\hline Mix D & 5 & 74.5 & 85.1 & 91.7 & 84.9 & 70.1 & 71.6 & 75.9 & 78.8 \\
\hline Mix D & 15 & 81.7 & 81.5 & 88.6 & 80.8 & 66.4 & 66.4 & 77.1 & 74.3 \\
\hline Mix E & 5 & 81.3 & 66.9 & 94.9 & 85.2 & 73.3 & 72.0 & 74.6 & 84.1 \\
\hline SEM & & $2.4^{4}$ & $2.4^{4}$ & $2.4^{4}$ & $2.4^{4}$ & $1.6^{5}$ & $1.6^{5}$ & $1.6^{5}$ & $1.6^{5}$ \\
\hline
\end{tabular}

${ }^{1}$ Amounts mimicked the addition of $0.3,1,3,5$, or $15 \mathrm{~g} / \mathrm{d}$ of enzyme to the diets of dairy cows consuming $25 \mathrm{~kg} / \mathrm{d}$ of DM.

${ }^{2}$ Averages across alfalfa and soybean hulls. Significant effect of enzyme $(P<0.0001)$, fermentation time (FT; $P<0.0001)$, preincubation time (PI; $P<0.0001)$, enzyme $\times$ FT $(P<0.0001)$, enzyme $\times$ PI $(P<0.0001)$, FT $\times$ PI $(P<0.0001)$, and enzyme $\times$ FT $\times$ PI $(P<0.0001)$.

${ }^{3}$ Averages across corn gluten feed and corn silage. Significant effect of enzyme $(P=0.001), \mathrm{FT}(P<0.0001)$, PI $(P<0.0001)$, enzyme $\times$ FT $(P<0.0001)$, enzyme $\times$ PI $(P<0.0001)$, and enzyme $\times$ FT $\times$ PI $(P=0.0005)$. No significant effects for FT $\times$ PI $(P=0.11)$.

${ }^{4} \mathrm{SEM}$ for $\mathrm{n}=4$ (all enzyme treatments). SEM for control $(\mathrm{n}=8)=1.7$. Differences among the listed means for enzyme treatments of at least 6.6 are significant $(P=0.05)$. Differences between controls and other means of at least 5.7 are significant $(P=0.05)$.

${ }^{5} \mathrm{SEM}$ for $\mathrm{n}=4$ (all enzyme treatments). SEM for control $(\mathrm{n}=8)=1.1$. Differences among the listed means for enzyme treatments of at least 4.5 are significant $(P=0.05)$. Differences between controls and other means of at least 3.9 are significant $(P=0.05)$.

0.52 in experiment 3 for the enzyme $\times$ substrate interaction; data not shown). Thus, within the limits of the 4 substrates and the range of enzymes evaluated, we observed no enzyme specificity suggesting that the optimal enzyme would change depending on dietary ingredients. However, Beauchemin et al. (1997) studied the effect of enzyme treatments on barley- or corn-based diets fed to feedlot cattle and found that enzyme treatments improved the performance of cattle fed barley, but not of those fed corn. Similarly, Beauchemin et al. (2003) discussed data wherein the functionality of various enzyme preparations differed markedly, depending on the substrate on which it was tested. Our data, within the limits of the substrates and enzymes tested, does not agree with the conclusion of Beauchemin et al. (2003) that enzyme-feed specificity is an important issue.

Averaged across all other treatments, there were significant $(P<0.01)$ responses in IVDMD to enzymes in both experiments 2 and 3 (Table 4). Product FP800, which contained the greatest cellulase activity (Table 1), increased IVDMD more than did the other enzymes. Responses to FP800 were achieved with the smaller amounts $(0.3$ or $1.0 \mathrm{~g} / \mathrm{d})$, with no further response to the larger amounts in either experiment 2 or 3 . Product
XP500 (at $5 \mathrm{~g} / \mathrm{d}$ ) seemed to be nearly as efficacious as FP800 in improving IVDMD in experiment 3, but its response was somewhat less than that of FP800 in experiment 2. Gabrielson (1986) reported that an enzyme preparation containing the least xylanase activity and greatest cellulase activity showed the greatest hydrolytic potential of all enzyme preparations examined, suggesting that cellulase activity may be the key activity of fibrolytic enzymes for hydrolysis of feeds. Work by Eun et al. (2007) demonstrated a positive relationship between fiber digestibility of alfalfa and corn silage and the endoglucanase activity of the enzyme supplemented; a similar relationship was not observed between fiber digestion and xylanase activity. Both Eun et al. (2007) and Eun and Beauchemin (2007) demonstrated that enzymes with only endoglucanase activity improved the degradation of alfalfa fiber, but similar improvements in fiber digestion could be obtained with xylanases. Surprisingly, combinations of endoglucanase and xylanase did not improve digestion above that obtained with either enzyme independently.

Among the product mixes A, B, C, D, and E, comparisons can be made at the $5 \mathrm{~g} / \mathrm{d}$ amount to indicate the advantages of adding additional enzyme activities. Mix 
A represents the basic activities, with the other mixes representing addition of different activities. In general, mix A did not improve IVDMD (Table 4), but addition of pectinase activity (mix B) or galactomannase activity (mix C) seemed to improve IVDMD. Responses to the addition of pectinase and galactomannase were unexpected because the substrates for these enzyme activities (pectins, nonlignified hemicelluloses) are readily degraded by ruminal microbes. It is interesting that the addition of papain activity to mix $\mathrm{C}$ (in creating mix D) and the addition of fradiase activity to mix $\mathrm{C}$ (in creating mix E) led to less IVDMD than that of mix $\mathrm{C}$ alone (these comparisons were made at the $5 \mathrm{~g} / \mathrm{d}$ amount, which was tested for all the mixes). It is possible that decreases in the enzyme response to addition of these proteolytic enzymes resulted from the degradation of fibrolytic enzymes by the added proteases, although the effect was not exacerbated (as might be expected for proteolysis of enzymes) by increasing the preincubation time from 1 to $18 \mathrm{~h}$.

For IVDMD, responses to enzyme treatment in experiment 2 were somewhat dependent on the fermentation time and the preincubation time (Table 4). These interactions between enzyme treatment and other variables were not observed in experiment 3 . In experiment 2 , the enzymes were generally ineffective in increasing IVDMD at $24 \mathrm{~h}$ (Table 4), and the IVDMD were numerically decreased by most of the enzymes at $24 \mathrm{~h}$. However, at $48 \mathrm{~h}$ of fermentation, the response of IVDMD to enzyme treatment was relatively large. In contrast, in experiment 3 , responses to enzyme treatments were consistent between the 2 fermentation times.

The interaction noted for enzyme treatment and fermentation time for IVDMD in experiment 2 became increasingly complex when it was evaluated across preincubation times (enzyme $\times$ fermentation time $\times$ preincubation time, $P=0.01$; Table 4 ). The decreases in IVDMD in response to enzyme treatment at $24 \mathrm{~h}$ of fermentation were observed only for the 1-h preincubation and not for the 18-h preincubation. Enzymes yielded positive responses in IVDMD at $48 \mathrm{~h}$ regardless of the preincubation time. These interactions were not evident in experiment 3. Possible explanations for these interactions might be dependent on 2 separate effects of the enzymes on digestion. Positive responses would be expected because of the enzymes acting on structures of the plant cell walls and increasing access of ruminal microbes to the potentially fermentable fiber. The enzymes also could degrade structures that the microbes otherwise might not be able to act on within the time allotted. However, the enzymes may also have a negative impact on digestion by occupying binding sites on the plant cell wall that might otherwise be used by the microbes as a site for attachment, digestion, or both (Beauchemin et al., 2003). Under conditions of a short preincubation and a short fermentation time, the negative aspects of the enzymes might dominate the benefits of enzyme treatment. Similarly, this also might explain why the smaller amounts of enzymes might be more beneficial than the larger amounts.

Effect of Enzymes on VFA. In experiments 2 and 3 , changes in VFA production in response to enzyme treatment were not positively related to the changes in IVDMD (Table 5). This was particularly true in experiment 3 , in which there was a negative relationship between IVDMD and VFA concentration across the enzyme treatments. Only data for total VFA concentrations are presented in Table 5, because molar proportions of individual VFA were never greatly affected by enzyme addition. For the treatment combinations presented in Table 5 , means for molar proportions of acetate ranged from 0.605 to 0.623 in experiment 2 and from 0.610 to 0.624 in experiment 3 , means for the molar proportions of propionate ranged from 0.203 to 0.212 in experiment 2 and from 0.193 to 0.207 in experiment 3 , and means for the molar proportions of butyrate ranged from 0.098 to 0.110 in experiment 2 and from 0.115 to 0.124 in experiment 3.

Some interesting interactions of enzyme treatments with fermentation time and preincubation time were observed for VFA concentrations in experiment 2. For the 24-h fermentations with the 1-h preincubations, enzymes had little effect on VFA concentration (Table 5). However, for the 24-h fermentations with the 18-h preincubations, there were large increases in VFA concentrations in response to enzyme treatment. In contrast, VFA concentrations in 48-h fermentations were depressed by the enzyme treatments regardless of the preincubation period, although the depression in response to enzyme treatment was greater when the preincubation period was $18 \mathrm{~h}$ than when it was $1 \mathrm{~h}$ (enzyme $\times$ fermentation time $\times$ preincubation time, $P<0.01$ ).

\section{Experiment 4: Solubilization of Substrates by Enzymes}

Enzyme treatment significantly altered the residue remaining after incubation with only the enzyme, but, in general, the residue remaining was increased by the enzyme treatment (Table 6). Changes in response to the enzymes were generally small and did not seem to be related to the changes in IVDMD in experiments 2 and 3. From these results, we can conclude that a simple incubation of the substrate with the enzyme will not be efficacious in predicting the effects of the enzymes on ruminal fermentation. 
Table 6. Effect of preincubation on substrate residues (experiment 4)

\begin{tabular}{|c|c|c|c|c|c|}
\hline Enzyme & Amount $^{1}$ & Alfalfa & $\begin{array}{l}\text { Corn gluten } \\
\text { feed }\end{array}$ & $\begin{array}{l}\text { Soybean } \\
\text { hulls }\end{array}$ & $\begin{array}{l}\text { Corn } \\
\text { silage }\end{array}$ \\
\hline & & \multicolumn{4}{|c|}{ \% remaining ${ }^{2}$} \\
\hline None & 0 & 63.5 & 70.8 & 79.5 & 76.0 \\
\hline FP800 & 0.3 & 66.4 & 73.8 & 79.9 & 75.6 \\
\hline FP800 & 1 & 64.8 & 69.9 & 79.5 & 77.2 \\
\hline FP800 & 3 & 64.8 & 71.1 & 79.4 & 75.4 \\
\hline FP800 & 5 & 63.9 & 70.3 & 79.0 & 74.2 \\
\hline XP500 & 5 & 63.6 & 70.6 & 78.6 & 75.0 \\
\hline Mix A & 5 & 64.8 & 72.1 & 78.5 & 75.8 \\
\hline Mix B & 5 & 66.2 & 73.1 & 80.9 & 78.2 \\
\hline Mix C & 1 & 67.5 & 73.6 & 82.2 & 79.3 \\
\hline Mix C & 5 & 66.4 & 73.1 & 81.3 & 78.1 \\
\hline Mix D & 5 & 63.6 & 70.1 & 78.2 & 74.6 \\
\hline Mix D & 15 & 62.5 & 69.2 & 77.4 & 73.1 \\
\hline Mix E & 5 & 67.0 & 74.0 & 82.1 & 79.1 \\
\hline SEM & & $0.50^{3}$ & $0.50^{3}$ & $0.50^{3}$ & $0.50^{3}$ \\
\hline
\end{tabular}

${ }^{1}$ Amounts mimicked the addition of $0.3,1,3,5$, or $15 \mathrm{~g} / \mathrm{d}$ of enzyme to the diets of dairy cows consuming $25 \mathrm{~kg} / \mathrm{d}$ of DM.

${ }^{2}$ Significant effects of substrate $(P<0.0001)$, enzyme $(P<0.0001)$, and substrate $\times$ enzyme $(P=0.04)$.

${ }^{3} \mathrm{SEM}$ for $\mathrm{n}=2$ (all enzyme treatments). SEM for control $(\mathrm{n}=4)=$ 0.35 . Differences among the listed means for enzyme treatments of at least 1.4 are significant $(P=0.05)$. Differences between controls and other means of at least 1.2 are significant $(P=0.05)$.

\section{Lactation Trial}

We studied the impact of fibrolytic enzymes (FP800) in the presence and absence of supplemental yeast to determine whether the responses to enzymes might be influenced by yeast supplementation. Although yeast supplementation has been observed to have little impact on digestion in dairy cows (Doreau and Jouany, 1998), it was considered possible that the yeast might improve the value of the enzymes by creating a favorable ruminal environment for their action or that the yeast might negate the potential for benefit from the enzymes by improving ruminal function independently of enzyme additions.

Dry matter intake averaged $29.3 \mathrm{~kg} / \mathrm{d}$, which is typical for cows maintained under our experimental conditions. Similarly, the average milk production $(43.9 \mathrm{~kg} / \mathrm{d})$ and efficiency of milk production (1.50 kg of milk/kg of DMI) in this trial were typical of expected production levels. Dry matter intake, milk production, milk efficiency, and production of all milk components were not affected by the addition of either fibrolytic enzymes or yeast (Table 7). Similarly, milk fat percentage, milk protein percentage, and SNF percentage were not affected by treatment. Surprisingly, milk lactose percentage demonstrated an interaction between yeast and a quadratic effect of the enzyme amount. The effect on milk lactose percentage is unusual because the concentration of milk lactose is typically very constant. Given the small magnitude of response, this statistically significant interaction was not considered to be biologically important.

Body weight change over each period demonstrated a quadratic effect of the fibrolytic enzyme because weight gain was less for cows receiving the intermediate amounts of enzyme (5 and $10 \mathrm{~g} / \mathrm{d}$ ) than for those fed either no enzyme or the highest amount (Table 7). Although the effect on efficiency of milk production was not significant, the BW changes mirror the changes in milk efficiency, suggesting that the slight differences might be due to repartitioning of energy between milk and body reserves for cows receiving different amounts of enzymes. This relationship is simply pointed out to demonstrate that the treatment response in BW change was probably not due to depressions in energy release from the diet for the intermediate enzyme amounts. Changes in BCS were not affected by treatment.

Taken as a whole, the data demonstrate that there were no production responses to the addition of either enzymes or yeast to the diets of lactating cows under our experimental conditions. Some of the previous studies that demonstrated positive responses to yeast supplementation were conducted under conditions of heat stress (Schingoethe et al., 2004) or during the transition phase (Dann et al., 2000), with the postulation that yeast reduces some of the digestive disturbances related to variations in feed intake associated with the stressful environment. Our experiment was conducted during the winter and early spring, so cows did not experience heat stress. Cows were maintained in tie stalls, and conditions were not stressful for the cows. In addition, all cows were at least 59 DIM, so there were no stresses related to the transition into lactation during our trial. Our lack of response to yeast supplementation should not be extrapolated to cows maintained under more stressful environments.

Responses to enzyme supplementation should be most clearly demonstrated under the low-stress conditions of our experiment, in which cows could easily respond to changes in energy availability from the diet. It is possible that lower amounts of the enzyme mixture would have been beneficial. In some previous experiments, responses to enzymes have been reported at lower enzyme amounts, with higher levels of enzymes being unable to yield the same benefits. In our in vitro studies with FP800, we observed that the response was dependent on the enzyme amounts. In experiment 1 , amounts of FP800 calculated to mimic 1 or $5 \mathrm{~g} / \mathrm{d}$ fed to a lactating dairy cow yielded a response that was greater than could be achieved with amounts of 15 or $30 \mathrm{~g} / \mathrm{d}$. In experiments 2 and 3, responses to FP800 were positive and essentially the same for amounts ranging from 0.3 to $5 \mathrm{~g} / \mathrm{d}$. It is unknown whether lower levels of FP800 would lead to production responses, but this possibility cannot be ex- 
Table 7. Performance of lactating dairy cows fed combinations of yeast and fibrolytic enzymes

\begin{tabular}{|c|c|c|c|c|c|c|c|c|c|}
\hline \multirow[b]{3}{*}{ Item } & \multicolumn{4}{|c|}{ No yeast } & \multicolumn{4}{|c|}{ Yeast, $5 \mathrm{~g} / \mathrm{d}$} & \multirow[b]{3}{*}{ SEM } \\
\hline & \multicolumn{4}{|c|}{ Enzyme, g/d } & \multicolumn{4}{|c|}{ Enzyme, g/d } & \\
\hline & 0 & 5 & 10 & 15 & 0 & 5 & 10 & 15 & \\
\hline $\mathrm{n}$ & 10 & 10 & 10 & 12 & 10 & 10 & 10 & 12 & \\
\hline DMI, kg/d & 29.8 & 29.3 & 28.9 & 29.6 & 29.5 & 28.8 & 29.0 & 29.4 & 0.36 \\
\hline Milk, kg/d & 44.0 & 44.3 & 43.4 & 44.1 & 44.2 & 44.0 & 43.5 & 43.6 & 0.72 \\
\hline Milk fat, $\mathrm{kg} / \mathrm{d}$ & 1.55 & 1.60 & 1.51 & 1.51 & 1.54 & 1.54 & 1.55 & 1.55 & 0.042 \\
\hline Milk protein, $\mathrm{kg} / \mathrm{d}$ & 1.38 & 1.38 & 1.34 & 1.38 & 1.37 & 1.38 & 1.35 & 1.38 & 0.027 \\
\hline Milk lactose, kg/d & 2.11 & 2.18 & 2.12 & 2.15 & 2.17 & 2.12 & 2.12 & 2.12 & 0.038 \\
\hline Milk SNF, kg/d & 3.89 & 3.99 & 3.87 & 3.94 & 3.95 & 3.90 & 3.88 & 3.90 & 0.068 \\
\hline Milk/DMI & 1.48 & 1.52 & 1.50 & 1.49 & 1.50 & 1.53 & 1.50 & 1.49 & 0.018 \\
\hline Milk fat, $\%$ & 3.54 & 3.62 & 3.48 & 3.43 & 3.51 & 3.52 & 3.57 & 3.57 & 0.094 \\
\hline Milk protein, \% & 3.14 & 3.14 & 3.10 & 3.14 & 3.10 & 3.14 & 3.13 & 3.16 & 0.032 \\
\hline Milk lactose, $\%^{1}$ & 4.79 & 4.92 & 4.89 & 4.88 & 4.91 & 4.81 & 4.86 & 4.85 & 0.034 \\
\hline Milk SNF, \% & 8.85 & 9.02 & 8.94 & 8.96 & 8.94 & 8.88 & 8.92 & 8.95 & 0.054 \\
\hline MUN, mg/dL & 16.4 & 16.7 & 16.7 & 16.6 & 17.0 & 16.7 & 16.9 & 16.9 & 0.37 \\
\hline Initial BW, kg & 609 & 619 & 622 & 615 & 612 & 614 & 620 & 609 & 4.5 \\
\hline BW change, $\mathrm{kg} / 28 \mathrm{~d}^{2}$ & 11 & 1 & -3 & 5 & 7 & 3 & 1 & 10 & 4.3 \\
\hline Initial BCS & 2.37 & 2.62 & 2.62 & 2.61 & 2.50 & 2.64 & 2.73 & 2.59 & 0.10 \\
\hline BCS change/28 d & 0.23 & -0.04 & 0.26 & 0.21 & 0.05 & -0.12 & 0.05 & 0.17 & 0.14 \\
\hline
\end{tabular}

${ }^{1}$ Interaction between yeast and quadratic effect of enzyme amount $(P<0.05)$.

${ }^{2}$ Quadratic effect of enzyme amount $(P<0.05)$.

cluded because amounts of enzyme below $5 \mathrm{~g} / \mathrm{d}$ were not tested.

In some cases, the method of adding fibrolytic enzymes to the diets of dairy cows can influence responses. Work by Bowman et al. (2002) suggested that it is best to add fibrolytic enzymes to as large a portion of the diet as possible. They observed greater improvements in digestion when fibrolytic enzymes (predominantly xylanase and cellulase) were added to the entire concentrate (45\% of diet) rather than to only a supplement ( $4 \%$ of diet) or a premix (0.2\% of diet). In contrast, Yang et al. (1999) demonstrated that digestion was affected more by the total amount of enzyme added than by whether the enzymes were added to the forage or the concentrate, although in that study, enzymes were added to a large proportion of the diet in all cases. Yang et al. (2000) observed better responses when fibrolytic enzymes were added to the concentrate than when they were added to the TMR. Clearly, the method of enzyme addition to dairy diets can affect the response, although our understanding in this area is far from complete. In our study, dry enzymes were mixed with a portion of the diet during the process of feeding and thus would not be in close contact with dietary components until consumed by the cow. Alternative methods of enzyme application might have yielded better results.

It is possible that our experimental design may have limited our ability to detect responses to treatments. With a Latin square design, responses that require long periods of time to manifest will not be detected. Moreover, carryover effects that last more than our $14 \mathrm{~d}$ of adaptation could confound results. It is also possible that improvements in diet digestion might be manifested to a greater extent in tissue deposition than in milk production. Although we measured BW and BCS during the trial as assessments of tissue reserves, these criteria were not extremely sensitive measures over the 28-d periods.

\section{CONCLUSIONS}

The most interesting observations were 1) that IVDMD was increased by addition of enzymes, with the response being greatest with FP800, even when FP800 was added in amounts less than that of the other enzymes, and 2) that VFA concentrations were often inversely related to $\mathrm{DM}$ disappearance, a response that we cannot easily explain.

The enzyme preparations that we studied were capable of acting on all the substrates we tested. The conclusion that FP800 was the most efficacious enzyme was based on the magnitude of response, as well as the fact that responses were achieved with smaller amounts of the enzyme. The greater activity of cellulase in FP800 than in the other enzyme mixes suggests that cellulase might be the most important activity.

Improvements in IVDMD in response to the enzymes were not mimicked by increases in VFA concentrations. If this response also occurred in the animal, feed intake might be increased because of more rapid breakdown of feed particles, but digestibility might not improve if the end products do not undergo fermentation.

The interactions between the enzymes and other variables that were tested are likely the result of several 
different actions of the enzymes, and this may partly explain why cattle respond better to intermediate amounts of dietary enzyme supplements than to larger amounts.

Although the fibrolytic enzymes we evaluated were capable of increasing IVDMD, the enzyme mixture that was most efficacious in vitro did not affect the lactational performance of dairy cows. Although it is possible that the enzyme lacks efficacy in vivo, it is also possible that the amount of enzyme and method of application to the diet are factors that limited its effectiveness in vivo.

\section{ACKNOWLEDGMENT}

The research support provided by Saf Agri (Milwaukee, WI) is greatly appreciated.

\section{REFERENCES}

Beauchemin, K. A., D. Collombatto, D. P. Morgavi, and Y. Z. Yang. 2003. Use of exogenous fibrolytic enzymes to improve feed utilization by ruminants. J. Anim. Sci. 81(E. Suppl. 2):E37-E47.

Beauchemin, K. A., S. D. M. Jones, L. M. Rode, and V. J. H. Sewalt. 1997. Effects of fibrolytic enzymes in corn or barley diets on performance and carcass characteristics of feedlot cattle. Can. J. Anim. Sci. 77:645-653.

Beauchemin, K. A., L. M. Rode, M. Maekawa, D. P. Morgavi, and R. Kampen. 2000. Evaluation of a nonstarch polysaccharidase feed enzyme in dairy cow diets. J. Dairy Sci. 83:543-553.

Beauchemin, K. A., L. M. Rode, and V. J. H. Sewalt. 1995. Fibrolytic enzymes increase fiber digestibility and growth rate of steers fed dry forages. Can. J. Anim. Sci. 75:641-644.

Beauchemin, K. A., W. Z. Yang, and L. M. Rode. 1999. Effects of grain source and enzyme additive on site and extent of nutrient digestion in dairy cows. J. Dairy Sci. 82:378-390.

Bentley Instruments. 1984. Bentley 2000: Accurate Infrared Analyzer for Dairy Products. Bentley Instruments Inc., Chaska, MN.

Bentley Instruments. 1998. The ChemSpec 150 User's Guide. Bentley Instruments Inc., Chaska, MN.

Bowman, G. R., K. A. Beauchemin, and J. A. Shelford. 2002. The proportion of the diet to which fibrolytic enzymes are added affects nutrient digestion by lactating dairy cows. J. Dairy Sci. 85:3420-3429

Dann, H. M., J. K. Drackley, G. C. McCoy, M. F. Hutjens, and J. E. Garrett. 2000. Effects of yeast culture (Saccharomyces cerevisiae) on prepartum intake and postpartum intake and milk production of Jersey cows. J. Dairy Sci. 83:123-127.

Doreau, M., and J. P. Jouany. 1998. Effect of a Saccharomyces cerevisiae culture on nutrient digestion in lactating dairy cows. J. Dairy Sci. 81:3214-3221.

Eun, J.-S., and K. A. Beauchemin. 2007. Assessment of the efficacy of varying experimental exogenous fibrolytic enzymes using in vitro fermentation characteristics. Anim. Feed Sci. Technol. 132:298315.

Eun, J.-S., K. A. Beauchemin, and H. Schulze. 2007. Use of exogenous enzymes to enhance in vitro fermentation of alfalfa hay and corn silage. J. Dairy Sci. 90:1440-1451.
Feng, P., C. W. Hunt, G. T. Pritchard, and W. E. Julien. 1996. Effect of enzyme preparations on in situ and in vitro degradation and in vivo digestive characteristics of mature cool-season grass forage in beef steers. J. Anim. Sci. 74:1349-1357.

Forwood, J. R., D. A. Sleper, and J. A. Henning. 1990. Topical cellulase application effects on tall fescue digestibility. Agron. J. 82:909-913.

Gabrielson, B. C. 1986. Evaluation of marketed cellulases for activity and capacity to degrade forage. Agron. J. 78:838-842.

Higginbotham, G. E., E. J. dePeters, S. L. Berry, and A. Ahmadi. 1996 Effect of adding a cell wall degrading enzyme to a total mixed ration for lactating dairy cows. Prof. Anim. Sci. 21:81-85.

Hristov, A. N., T. A. McAllister, and K.-J. Cheng. 2000. Intraruminal supplementation with increasing levels of exogenous polysaccharide-degrading enzymes: Effects on nutrient digestion in cattle fed a barley grain diet. J. Anim. Sci. 78:477-487.

Lewis, G. E., W. K. Sanchez, R. Treacher, G. T. Pritchard, and P. Feng. 1996. Effect of direct-fed fibrolytic enzymes on digestion of a foragebased diet fed to beef steers. J. Anim. Sci. 74:3020-3028.

McDougall, E. I. 1948. Studies on ruminant saliva. I. The composition and output of sheep's saliva. Biochem. J. 43:99-109.

Morgavi, D. P., K. A. Beauchemin, V. L. Nsereko, L. M. Rode, A. D. Iwaasa, W. Z. Yang, T. A. McAllister, and Y. Wang. 2000. Synergy between ruminal fibrolytic enzymes and enzymes from Trichoderma longibrachiatum in degrading fiber substrates. J. Dairy Sci. 83:1310-1321.

Morgavi, D. P., V. L. Nsereko, L. M. Rode, K. A. Beauchemin, T. A. McAllister, A. D. Iwaasa, Y. Wang, and W. Z. Yang. 2001. Resistance of feed enzymes to proteolytic inactivation by rumen microorganisms and gastrointestinal proteases. J. Anim. Sci. 79:16211630.

Rode, L. M., W. Z. Yang, and K. A. Beauchemin. 1999. Fibrolytic enzyme supplements for dairy cows in early lactation. J. Dairy Sci. 82:2121-2126.

Schingoethe, D. J., K. N. Linke, K. F. Kalscheur, A. R. Hippen, D. R. Rennich, and I. Yoon. 2004. Feed efficiency of mid-lactation dairy cows fed yeast culture during summer. J. Dairy Sci. 87:4178-4181.

Sutton, J. D., R. H. Phipps, D. E. Beever, D. J. Humphries, G. F. Hartnell, J. L. Vicini, J. L., and D. L. Hard. 2003. Effect of method of application of a fibrolytic enzyme product on digestive processes and milk production in Holstein-Friesian cows. J. Dairy Sci. 86:546-556.

Van Soest, P. J., J. B. Robertson, and B. A. Lewis. 1991. Methods for dietary fiber, neutral detergent fiber, and nonstarch polysaccharides in relation to animal nutrition. J. Dairy Sci. 74:3583-3597.

Wang, Y., T. A. McAllister, L. M. Rode, K. A. Beauchemin, D. P. Morgavi, V. L. Nsereko, A. D. Iwaasa, and W. Yang. 2001. Effects of an exogenous enzyme preparation on microbial protein synthesis, enzyme activity and attachment to feed in the rumen simulation technique (Rusitec). Br. J. Nutr. 85:325-332.

Wildman, E. E., G. M. Jones, P. E. Wagner, R. L. Boman, H. F. Troutt, Jr., and T. N. Lesch. 1982. A dairy cow body condition scoring system and its relationship to selected production characteristics. J. Dairy Sci. 65:495-501.

Yang, W. Z., K. A. Beauchemin, and L. M. Rode. 1999. Effects of an enzyme feed additive on extent of digestion and milk production of lactating dairy cows. J. Dairy Sci. 82:391-403.

Yang, W. Z., K. A. Beauchemin, and L. M. Rode. 2000. A comparison of methods of adding fibrolytic enzymes to lactating cow diets. J. Dairy Sci. 83:2512-2520.

ZoBell, D. R., R. D. Wiedmeier, K. C. Olson, and R. J. Treacher. 2000. The effect of an exogenous enzyme treatment on production and carcass characteristics of growing and finishing steers. Anim. Feed Sci. Technol. 87:279-285. 